\title{
Tourism and Ethics in Japanese Shrinking Cities
}

\author{
MARI ANNA FUJITA \\ University of British Columbia
}

\begin{abstract}
Within Japan, a slow moving crisis is underway. The elderly population is growing, yet the overall population is shrinking, and cities and villages across the country are shrinking. By 2040, the National Institution of Population and Social Security has predicted that the population will drop 20 million from $127 \mathrm{mil}$. to $107 \mathrm{mil}$. people. And that in this same time period, 896 cities, towns, and villages are predicted to become extinct. ${ }^{1}$
\end{abstract}

The shrinking of Japanese cities is not a new phenomenon but one that has been ongoing since Japan rapidly urbanized after World War II. Japan is often referred to as the poster child of urbanization. As the geographer André Sorenson writes in his book The Making of Urban Japan, "superlatives are routinely deployed in the description of Japanese economic growth and urban development." ${ }^{2}$ Japan urbanized faster than any other country, has one of the largest urban regions in the world, and has an urban population that exceeds $90 \%$ of the population. However, Japan's rapid urbanization has resulted in the depopulation of areas that are outside of the magnetic centres of Tokyo, Osaka and Nagoya.

The response by the Central Government of Japan is to look to tourism to breathe life back into shrinking cities and to save the economy overall. Through a multi-tiered program of funding development projects, softening visa policies, and the expansion of hotels, airports and flight itineraries / frequencies, the government is making Japan more accessible physically, financially, and psychologically. Ambitions targets for annual number for foreign visitors have been set, escalating with the Olympic Games that will be hosted in Tokyo in $2020 .^{3}$

As all levels of society in Japan prepare for a future married to tourism, the country is undergoing extreme social and spatial transformation. Among these changes: the shape of the government and its Ministries is changing ${ }^{4}$, budgets are changing to prioritize the accommodation of tourism (instead of renovating the hospital, build a new train station), education is changing to support the learning of English earlier, the job market is changing (cow farmers are now flipping burgers in the hospitality business), the physical development of cities is changing (more tourist attractions! more hotels!), visual language is changing (signage now reflects international standards $)^{5}$, and overall: everyday people's lives are changing to better interact with and serve tourists.
Japan is not alone in its quest to rebuild an economy around tourism. According to the United Nations World Tourism Organization (UNWTO), 940 million people engaged in international tourism in 2010, generating $\$ 919$ billion U.S. dollars. UNWTO Facts and Figures show roughly a 5\% increase in tourism every year since 2010, making tourism one the world's largest industries as well as one of the fastest-growing industries. ${ }^{6}$

A critical component of the growing tourism industry is a growing awareness that tourism changes places. Research, theories, codes, and ethics have been in development since the 1950's, when tourism was truly established as an industry, to study the phenomenon of tourism. The Global Code of Ethics for Tourism (GCET) is a set of principles crafted by the United Nations World Tourism Organization, and adopted in 1999. The Code of Ethics guides all stakeholders in the tourism industry towards "Responsible and sustainable tourism ... [that takes] ... ethical questions on board and reconciles any tensions between economy and ecology, environment and development, openness and the protection of social and cultural identities." ${ }^{7}$

This paper will use the "Art Islands" in the Seto Inland Sea as a case study to consider how tourism oriented development is bringing about change to the three islands. Established codes of ethics will be used as a framework against which to measure and contemplate how Naoshima, Teshima and Inujima Island have and will continue to change. These shrinking cities and their new economies challenge the existing models and theories of the city that we have as architects, landscape architects, designers, and historians of the city. As tourism has become one of the fastest-growing industries, to consider ethics in tourism as it relates to the design and construction of the built environment, is an urgent project.

\section{THE ART ISLANDS OF THE SETO INLAND SEA}

Japan has a history of creating and promoting tourism around art and architecture. The latest success story of such tourism is that of the "Art Islands" Naoshima, Teshima and Inujima, located south of Okayama city in Kagawa Prefecture. The islands are host to local residents, some industry, and a multitude of art-related projects by the Fukutake Foundation, the non-profit wing of Benesse Holdings, Inc. The art-related projects range from a fiberglass bubble bike storage building by SANAA, to a $9^{\prime}$ tall yellow polka-dot pumpkin on a pier sculpted by Yoyoi Kusama, to "art houses" which are 


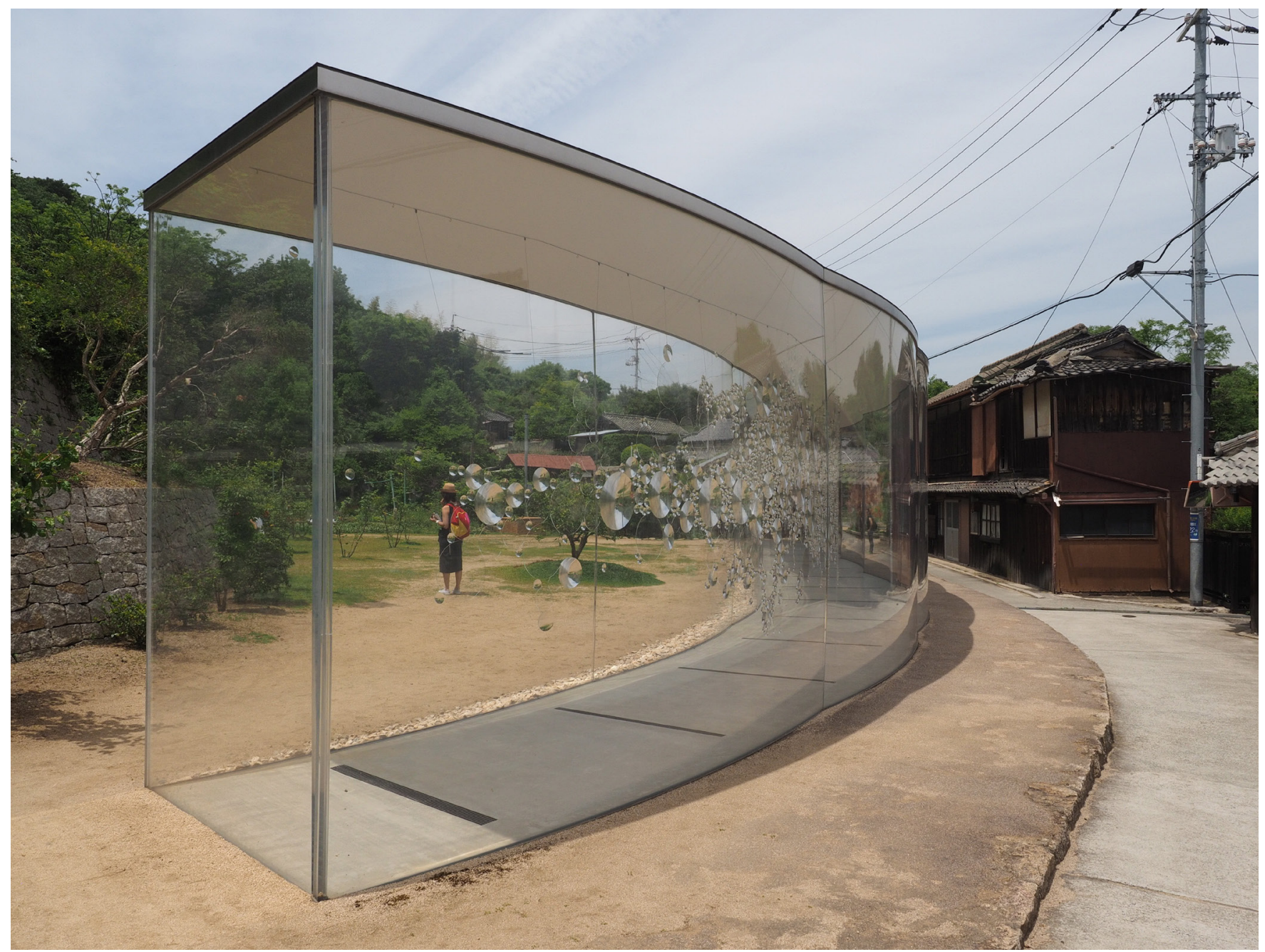

Figure 1: S-Art House, Haruka Kojin and Kazuyo Sejima, Inujima

installations by architects and artists in abandoned houses, to epic museums by Tadao Andoa, Ryue Nishizawa and Hiroshi Sambuichi. Every three years an art triennale is held on the islands. In the first two editions of the triennale, over a million visitors traveled by train and ferry to these small islands with populations that range from 3000 people (Naoshima) to 50 (Inujima).

Benesse Holdings, Inc. started up in 1955 as Fukutake Publishing Co., a publisher in Okayama that specialized in educational materials. Soichiro Fukutake, the son of the original founder, took over the company in 1986 and broadened the company's mission to a "multi-faceted building operation in step with the changing times in Japan, particularly trends such as globalization, declining birth rate, and societal aging". ${ }^{9}$ The company's activities diversified to include a broader set of publications as well as nursing care services, language education, business education, and more. Benesse is a financially successful venture, Soichiro Fukutake is one of the richest men in Japan, and he is an art collector.
The Fukutake Foundation was established in 1985 and "aims to revive local communities on three islands at present (Naoshima, Teshima, Inujima) through contemporary art that draws on the distinctive regional history, culture, and nature, and convey the charms of these islands to the world". ${ }^{10}$ The mission statement of the development on the islands is a commitment "committed to foster a relationship of mutual growth between art and the region, aiming to make a positive contribution to the local communities."11 The Fukutake Foundation calls the project "Benesse Art Site Naoshima" and boldly stamps its brand on all art-related activities on the islands, small to large.

For the past three years, Conde Nast Traveler has written a feature on one or all of the "Art Islands". In the most recent article (March 10, 2017), the islands were recommended as one of three places to visit in Japan (the other two being Tokyo and Kyoto). ${ }^{12}$

The first Benesse Art Site Naoshima project was the Benesse House Museum, designed by Tadao Ando, and which opened in 1992. The Benesse House Museum is both a museum to house Fukutake's art collection, as well as a luxury hotel. 


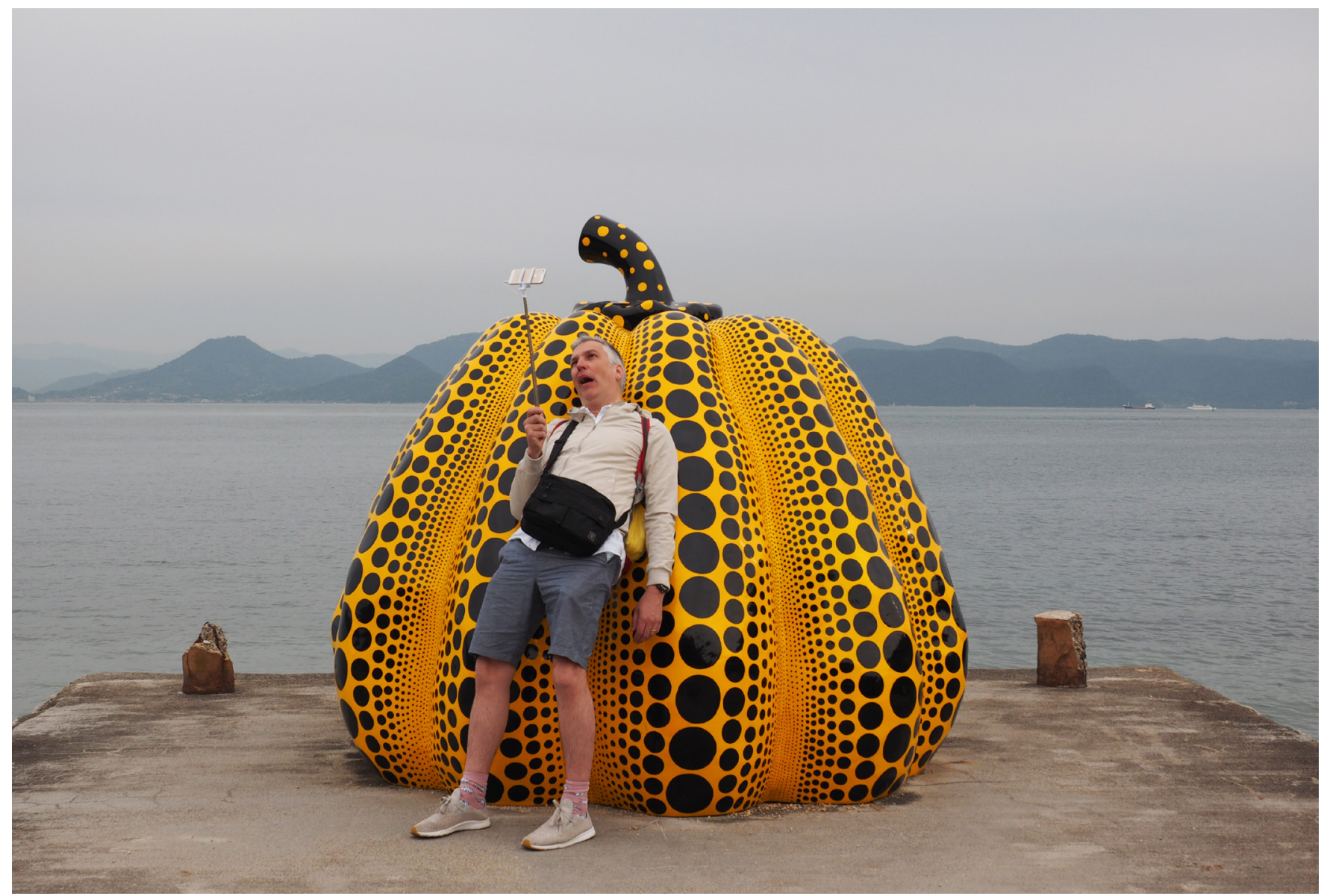

Figure 2: Tourist takes a selfie at Pumpkin, Yayoi Kusama, Naoshima

Rooms cost about $\$ 500$ to $\$ 600$ USD a night and are booked out months in advance. A subsequent project by Tadao Ando is the Chichu Art Museum, which opened in 2004 and holds permanently installed works of three artists: five paintings in the Water Lilies series by Claude Monet, one installation by Walter de Maria, and a room featuring three light installations by James Turrell. There are several major works by SANAA, a museum by Ryue Nishizawa, installations by Sou Fujimoto, Yayoi Kusama, Iwan Baan, Olafur Eliasson, Shinro Ohtake, Haruka Kojin, with more works arriving every year.

\section{BENESSE ART SITE NAOSHIMA: POTENTIALS AND PROBLEMS}

On first glance, the Benesse Art Site Naoshima is a brilliant response to the faltering economies and dwindling populations on Naoshima, Teshima and Inujima. The long-term investment of the Benesse / Fukutake Foundation in partnership with local government and the private sector is a recipe for success. Benesse owns a significant portion of Naoshima, and has converted the island's southern side into a wellorganized and luxurious space for art viewing, fine meals, and relaxation. All of the service workers wear uniforms in simple cuts with neutral colours, so to occupy Benesse-land is to be surrounded by a sizeable cohort of hueless staff in clean white sneakers. The only way to move around this part of the island is by foot and bike, or more likely by the free Benesse shuttle that makes its rounds every twenty minutes between Benesse House Museum, Chichu Art Museum, Lee Ufan Museum, and the beach with the big Kusama pumpkin sculpture. The two main villages with their ferry terminals occupy the middle part of the island. Between these two ports tourists, art houses, and commerce intersect with the everyday life of the island's occupants. The single public bus route in Naoshima is traversed by two buses covered in red and yellow Yayoi Kusama polka dots. The bus passes by the island's City Hall, its school, senior's home, and the 7-11 convenience store. Anyone not staying at Benesse House will stay in the middle part of the island and experience a more varied landscape in which art and daily life overlap. Finally the North side of the island is "still dominated by the [Mitsubishi] factory and its facilities. ${ }^{13}$

The Mitsubishi Factory, once the major employer on Naoshima, is still in operation but at a reduced capacity. Teshima's major industry was farming and materials recycling; Inujima was always the smallest of the three islands and once boasted a population of 1,500 but is now a small fishing village with a population of 50 people. The Benesse claims that its museums and hotels employ 300 people, twothirds of whom work part time. ${ }^{14}$ The shift in employment on 


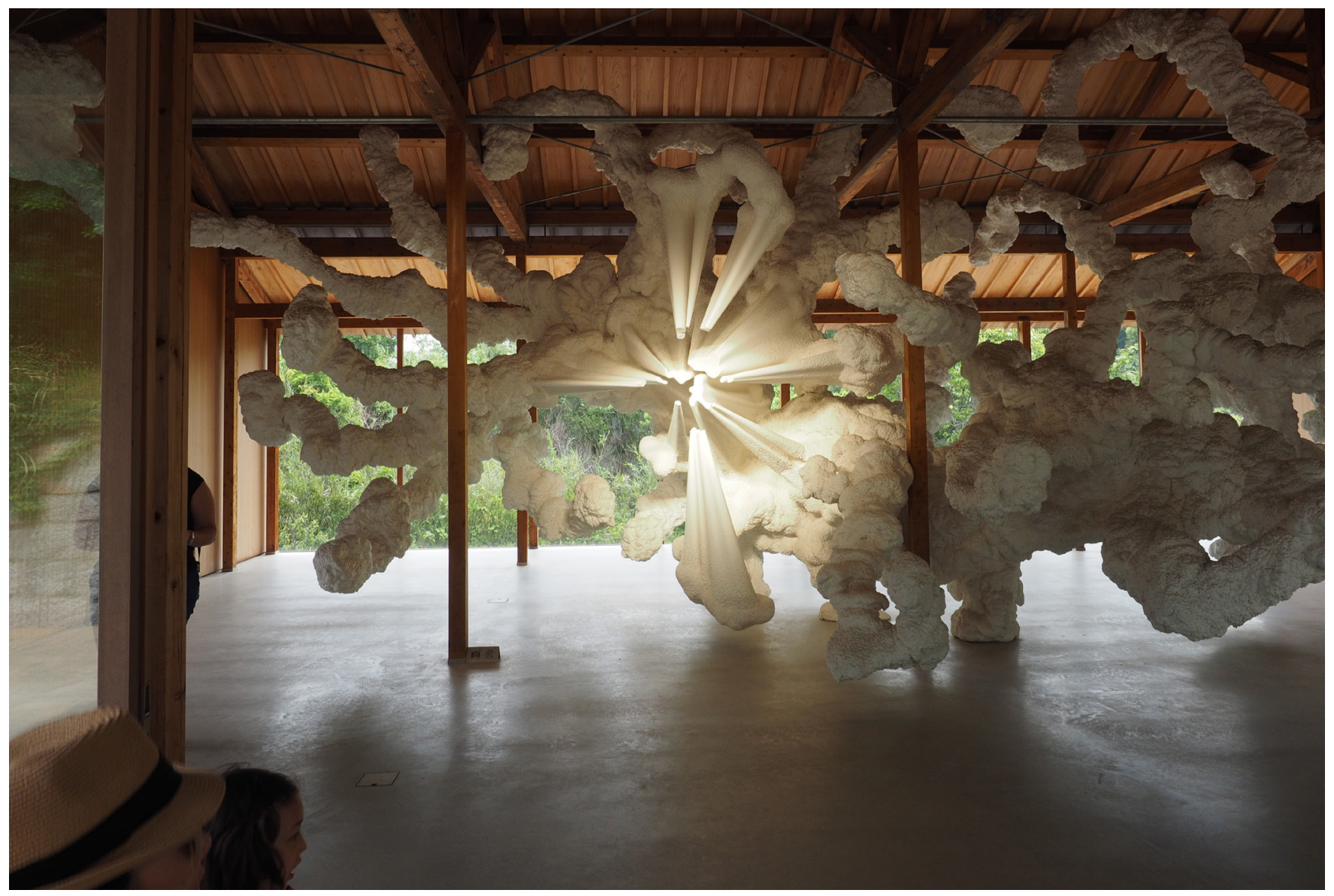

Figure 3: F-Art House, Kohei Nawa, Inujima

these islands, Naoshima in particular, is from skilled, full-time work to seasonal and part time jobs in the service industries for a low wage. ${ }^{15}$

During the Setouchi International Art Festival, held every three years, a swarm of volunteers descends on the islands to assist in the running of the festival. This army of volunteers, called "koebitai" (little shrimp squad) are, in operational terms, the staff of the festival, but economically they function as their own class of tourist, contributing to the economy through travel expenses, lodging (although this is sometimes provided to volunteers) and by eating and drinking on the islands.

Tourism makes a healthy contribution to the economy of the islands. To accommodate the influx of tourists for the trienniale, there has been a series of creative responses to providing housing: from hostels to bed and breakfasts, to purpose-built hotels that cater to a spectrum of tourists (from backpackers to luxury tourists). For example, a bed and breakfast near Honmura, the second ferry terminal on Naoshima, is a converted $100+$-year old family house that was vacated by the elderly owner and is now in the hands of the owner's married adult daughter who lives nearby in her own house. The daughter uses the traditional house to host anywhere from 3 to 16 guests at one time. Breakfast is served in the house's back room (similar to a detached garage), which the entrepreneurial daughter has converted into a cat café.

There is not enough current data to analyze the financial impact Benesse has had on Naoshima, Teshima and Inujima. However, the tensions between the locals, the tourists, and the Benesse operation fall into three main categories: the introduction of an elite class, the question of who the development is serving, and the question of the longevity of the Benesse project.

\section{THE ELITE CLASS}

The insertion of Benesse House Museum onto the island of Naoshima has created a space for a class of tourist that can afford to pay upwards of $\$ 500$ a night for a room. Part of the room cost covers the entrance fee to the various museums. Another part of the room cost is access to small Benesse vans that ferry these elite guests around the island. The vans are on demand, and operate outside of the public bus and free, scheduled Benesse shuttle system. The image of a welldressed foreign tourist being bowed to by the driver before stepping into a small beige private van is in stark contrast to the happy, polka-dot adorned public bus that transports locals and "normal" tourists alike. The distinction between 
elite and "normal" is troubling, and perhaps is most supported by the design aesthetic of the Benesse developments. Tadao Ando barely deviates from his signature monumental concrete slabs. The Lee Ufan museum, by another architect, is also formed by large concrete slabs cutting into the verdant landscape. The vans are beige; the uniforms of the service staff are formless in beige and white and include a small cloth beige cross-body bag. The bags are custom made for Benesse by the premium Japanese bag company Porter, and are worn by staff that collect tickets, are tasked with counting guests, or need to hold a small information pamphlet. Porter describes its products as "affordable luxury". ${ }^{16}$ The custommade Benesse bags are available for sale in the museum gift shops for about $\$ 90$ USD. The totalizing aesthetic of the Benesse feels like a bubble. The Chichu Art Museum and associated landscape would make a perfect set for a science fiction movie in which humans are created through in vitro fertilization and don't require food, sex, or humour. The heavy, scaleless, bunker-like, interior-oriented architecture could also be a believable setting for a high-tech prison.

Outside of the Benesse bubble, the locals and tourists overlap in a genial yet asymmetrical relationship of server and servee. Aesthetically there is a retro atmosphere at some of the restaurants, hearkening back to a naïve and ebullient post-war period marked by increased contact with the West and by remarkable economic growth. "I Love YU" Bath, an Art House Project by Shinro Ohtake, is an abandoned house turned into a public bath that is said to attract locals and tourists alike. The Art Setuichi website describes the project as "an art installation in which visitors can actually take a bath. Incorporates objects as diverse as pine trees planted on the roof and a stuffed baby elephant from a sex museum."17 The merry seniors who collect the fee at the front door, don I 湯 ( I love yu / I love hot water) t-shirts, and vigorously greet guests, appear to be oblivious to the sex museum objects in the space directly behind them. The t-shirts are among the many I 湯-branded pieces of merchandise designed by the artist and for sale on site.

It is uncomfortable to travel to Naoshima and observe the social tensions between elite tourists, 'normal' tourists (for lack of a better term), Benesse employees, and the local people. Tourism inherently carries with it asymmetries of position and power between the observer and the observed, the server and the servee. The elites intensify this condition.

\section{WHO DOES THE ART TOURISM SERVE?}

In 2016, the Naoshima Municipal Government published a brochure that itemized all of the recent architectural developments on the island. ${ }^{18}$ The brochure was printed in Japanese and is only available to the 3000 residents of Naoshima. It was intended not for public consumption but is instead an internally facing document that reveals to the people of Naoshima how all of their tax money and other contributions were spent.
A conversation with a local resident uncovers ambivalence about the new development on the island. The resident has lived on Naoshima her entire life and is and welcomes the business the art tourism brings, but questions some of the buildings that her tax dollars are paying for. ${ }^{19}$ Two buildings she identified as being problematic are: the Naoshima Ferry Terminal building by SANAA in Miyanoura and the other Port Terminal Building in Honmura. Ferry Terminal building, completed in 2006, is an elegant construction of thin mirrored slabs and columns. The building was not planned well, however, and the cars and trucks that drive over the covered areas to queue up to board the ferry have issues with the turning radii provided by the designers. The Honmura Port Terminal Building, completed ten years later, is an experimental structure made of light wooden beams and columns, covered by a composition of semi-transparent plastic bubbles that are 4-meters in diameter and made of a $5 \mathrm{~mm}$ thick fiber-reinforced polymer (RFP). ${ }^{20}$ It is much smaller than the Ferry Terminal on the other side of the island, and is designed to house bikes, a modest waiting area, and a single bathroom. The resident's concern with the bubble building is not related to its performance, but to its materiality. She is concerned about how it "looks dirty" at night. ${ }^{21}$ For both the projects, the resident explained that an "erai hito" or a respected and educated person recommended SANAA as excellent and capable architect for the projects. The fact that the resident questions the success of these two projects points to questions around agency and whose interests are met by the public spending supporting the projects.

\section{HOW WILL ART TOURISM IN THE SETO INLAND ISLANDS EVOLVE OVER TIME?}

Art and architectural tourism is not a new phenomenon in Japan. Historically Japanese cities and villages have carved out distinct identities based on the goods and products they produce such as a distinct type of pottery, a special form of pickle, or dried squid fished from the nearby sea. The idea of tourism within Japan was established during the Edo period through the development of the Tōkaido Road, a route that linked Edo (now Tokyo) to Kyoto. Architect Jilly Traganou describes it such: "The Tōkaidō...was not simply a means of transportation, but carried a strong figurative capacity, embodying a multitude of ideologies and imaginings that shaped travelers, artists and spectators."22 As early as 1691, Engelbert Kaempfer, the German explorer-writer, described the Tōkaidō as "more crowded than the public streets in any (of) the most populous towns in Europe." There are beautiful maps and guidebooks that describe the ways to travel the road (walk, horse, palanquin), how much each mode would cost, where the guesthouses were located, where the historic sites were located and so on. Hiroshige Ando's famous set of woodblock prints, Fifty-Three Stations of the Tōkaidō, was produced from fifty-three locations along the route. In its heyday as a roadway in the Edo period, the Tōkaidō route was the most prosperous space in Japan as local merchants capitalized on the flow of travellers. 


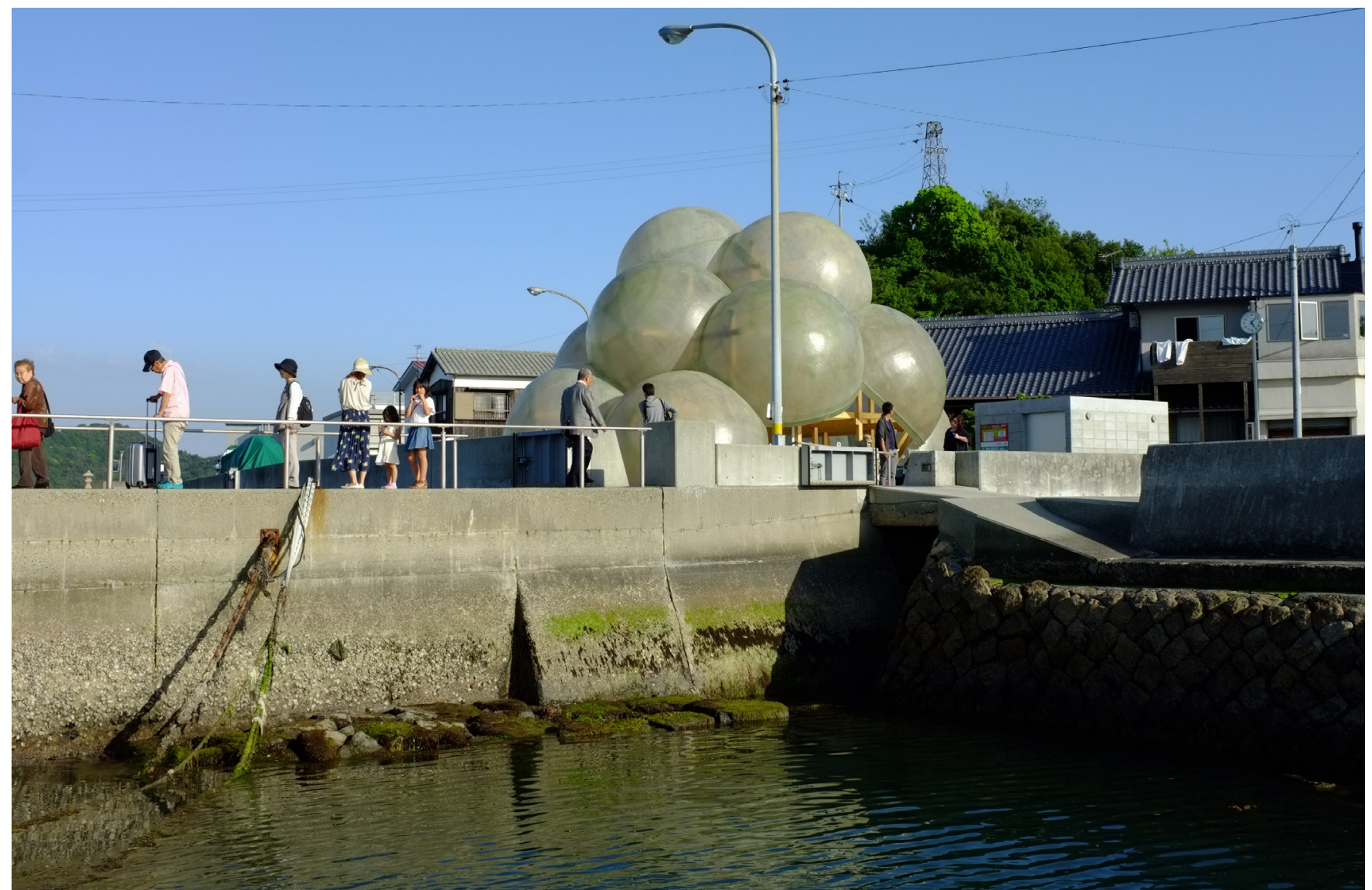

Figure 4: Honmura Port Building, SANAA, Naoshima

At the time Japan was experiencing a bubble economy in the 1980s and 1990s, the sense of infinite growth and of being able to afford luxury was felt in the urban cores. In rural areas, however, the booming economy drew money and people away; the buoyancy of the bubble did not extend to these areas. Prime Minister Nakasone initiated a program during his leadership (1982-1987) that encouraged rural areas to create "identity architecture". ${ }^{23}$ The next Prime Minister Takeshita went a step further to initiate the Furosato Sousei Jigyou "Hometown Creation Project." Between 1988 and 1989, 3,300 towns were handed $\$ 750,000$ USD each to support projects that would "creatively invigorate the "hometown spirit" of the area". ${ }^{24}$ It was during this time that the idea of using funds to develop distinct architectural projects that would support a sense of identity and local, was established across Japan.

The Nakagawa-machi Batō Hiroshige Museum of Art, designed by Kengo Kuma, holds a sizeable collection of prints by Hiroshige Ando. Batō is a depopulated rural town with the same problems shared by other towns with the same predicament. The gift of a collection of Hiroshige prints by a local family was the town's opportunity to save itself. The local municipality and the prefectural government shouldered the museum's $\$ 9.8$ million USD budget. The museum opened in 2000 and, for a few years enjoyed record rates of tourism. However, within ten years, the tourism has stagnated and Batō is in the same predicament it was in before Kengo Kuma and Hiroshige Ando rolled into town. "It is clear that the answers to the town's problems did not lie in the construction of a single brand-name museum. ${ }^{\prime 25}$ In 2005, to save itself, Batō went the way of many struggling towns in Japan and merged with adjacent municipalities. It is one city in the thousand that had to choose this future. By 2010, so many mergers had taken place across japan that the number of municipalities was reduced from approximately 3200 to fewer than $1800 .{ }^{26}$ In the case of Batō as well as the majority of the towns that have attempted to leverage art and architecture to generate tourism, the long-term prognosis is not a positive one.

In 2012 geographers Carolin Funck and Nan Chang performed a study to learn about what kind of tourists travel to the Seto Inland Sea. They concluded that the majority of tourists are not "ardent art fans" but instead would be members of the "culture class". ${ }^{27}$ The respondents list 'art' as the main reason they travelled to the islands, followed by 'to enjoy landscape', 'to eat local foods and products' and 'to recover from daily stress'. Surprisingly, 'architecture' received one of the lowest responses, ${ }^{28}$ which is humbling and also instructive for other towns that have not been educated on the Batō-effect. 
What appears to be a long running and successful project that uses architecture to support local identity is the Kumamoto Artpolis, initiated in 1988 as a partnership between the Government of Kumamoto Prefecture, and Arata Isozaki, the project's first commissioner. In its almost 30 years of existence, Isozaki and now Toyo Ito, the current commissioner, have worked with municipalities in the prefecture to help curate their urban realms and make good decisions about which architects they hire. The result is a growing series of distinctive buildings that are part of the everyday fabric of the city (a museum, a police station, an entrance to a major train station) that are used by the local people as well as visitors. Kumamoto Artpolis does not host a triennale, a festival, or any other event that overtly draws tourists to the region. Instead an exhibition of projects commissioned with the help of the Artpolis travels to sites around the world and is presented to an audience that is specifically interested in architecture. Kumamoto, like everywhere else in Japan, has a declining population but its economy is relatively intact in comparison to some of the other places mentioned in this paper. For this reason, the Artpolis project is using architecture as ... architecture, not as a vehicle to brand and attract the gaze of the tourist.

\section{ETHICS AND TOURISM}

In 2016, international tourism to Japan rose by $22 \%$ to 24 million visitors. ${ }^{29}$ On paper, the Central Government's program to increase tourism is working swimmingly. However, a 2016 McKinsey \& Company report on Japan's tourism industry identifies "skewed regional distribution" as an area that will need improvement in order for tourism to grow sustainably. ${ }^{30}$ If the majority of tourists are traveling to Tokyo, Osaka, and Kyoto, then the very pressing issues of dying economies, declining population, and shrinking cities is not being directly acted upon.

The "Art Islands" of the Seto Inland Sea are undergoing rapid social and spatial change. Issues that have arisen since Benesse Art Site Naoshima project first opened in 1992 include the development of an elite class on the islands, as well as tensions around who has agency, and who is being served by the art installations, infrastructure improvements, and opportunities in the hospitality industry. And finally, the future of the islands is uncertain; Japan has a long and sophisticated history of tourism, starting with the establishment of the Tōkaidō Road. In recent history, however, there are no raging success stories to point to and model. How success is measured is also not a simple matter, because the many

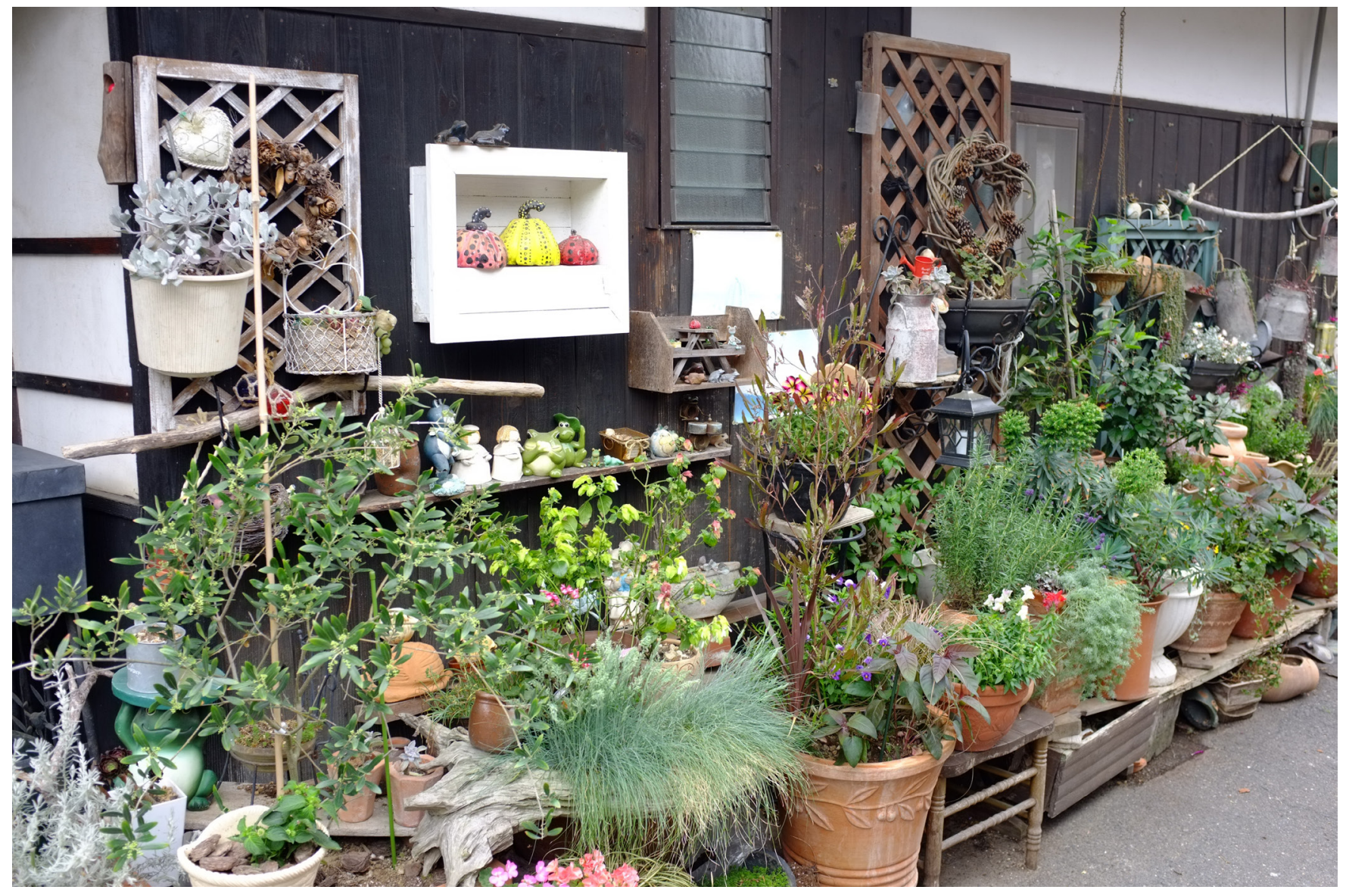

Figure 5: A Private Garden on a side-street in Honmura, Naoshima 
stakeholders involved in the development of a town inevitably have different agendas and values. The role ethics can play in the evaluation and design of a tourist site is therefore a critical lens that needs to be better utilized moving forward. A feel-good statement such as this one by Anthony Rausch, "Well-managed resources need to be recognized, valorized, exploited and sustained"31 fails to identify the who and the how.

The UNWTO Global Code of Ethics is a good starting point against which to consider and assess the myriad of issues that tourism brings about. Yet the code, too, contains vague language that fails to confront the complexity of a place like Naoshima.

\section{CONCLUSION}

As the population continues to decline on these islands, there is an opportunity for Benesse / the Fukutake Foundation to continue expanding their project. Abandoned houses can be sites for more art house installations, and failing farms on Teshima can be converted into sites for new sculptures. In the survey performed by Carolin Funck and Nan Chang, 67.1\% of the tourists polled expressed a willingness to visit Naoshima again. ${ }^{32}$ This is hopeful, and may help the overall project avoid falling to the same fate as Kengo Kuma's Hiroshige museum in Batō. Other shrinking islands, like the Oki Islands in the Sea of Japan, are closely watching Benesse Art Site Naoshima as they start to take action on a tourism strategy of their to slow down the inevitable.

Despite the tensions, many locals have internalized Benesse Art Site Naoshima and include miniature porcelain replicas of Yayoi Kusama's yellow and red pumpkin in their own semiprivate gardens or on shelves in their homes or restaurants (see image 05). The domestication of these famous sculptures may be interpreted as an act of vigorous ownership. Only on Naoshima Island has Kusama's work come to explore the infinite and sublime mixed into everyday life.

\section{ACKNOWLEDGEMENT}

Thank you to Amanda Lehring for supurb research support.

\section{ENDNOTES}

1 Eric Johnston, "Is Japan Becoming Extinct?" May 16, 2015, The Japan Times. https://www.japantimes.co.jp/news/2015/05/16/national/social-issues/japanbecoming-extinct/\#.WdM45LV-iis

2 Andre Sorenson. The Making of Urban Japan: Cities and Planning from Edo to the Twenty-First Century. The Nissan Institute/Routledge Japanese Studies Series. London: Routledge, 2003: 1.

3 The target for 2020 is 25 million foreign visitors. The New Growth Strategy Blueprint for Revitalizing Japan, June 18, 2010. Report by Japanese Ministry or Economy, Trade and Industry. http://www.meti.go.jp/english/policy/economy/ growth/report20100618.pdf

4 Japan: Tourism Staff to be increased by $50 \%$. May 26, 2017. https://www. bccjapan.com/news/2017/05/japan-tourism-staff-be-increased-50/

5 "How the Tourism Boom is Causing Japanese to Change its Controversial Symbol for Temples." http://sanpai-japan.com/2017/05/30/how-the-tourismboom-is-causing-japan-to-change-its-controversial-symbol-for-temples/
6 UNWTO Facts and Figures http://www2.unwto.org/facts/eng/vision.htm and GSCE Bitesize: Geography http://www.bbc.co.uk/schools/gcsebitesize/geography/tourism/tourism_trends_rev1.shtml

7 UNWTO Global Code of Ethics http://ethics.unwto.org/en/content/ resolutions-global-code-ethics-tourism

8 Benesse Setouchi International Art Festival Report 2010. http://www.benessehd.co.jp/en/csr/feature/2010_3/index.html

9 Benesse Holdings, Inc. Group History. http://www.benesse-hd.co.jp/en/about/ history.html

10 The Benesse Group and its Foundations. http://www.benesse-hd.co.jp/en/csr/ feature/2010_3/foundation.html

11 "Benesse Art Site Naoshima". http://benesse-artsite.jp/en/about/

12 Where to Go in Japan: 3 Places to Visit in 2017. Katherine LaGrave, March 10, 2017.https://www.cntraveler.com/story/ where-to-go-in-japan-3-places-to-visit-in-2017

13 Carolin Funck and Nan Chang, "The Development of Naoshima as an Art Tourism Site" in Tourism in Transitions: Recovering Decline, Managing Change. Dieter K. Mueller, Marck Wiekowski, eds. Springer, 2017: p86.

14 H. Shibata. Doseitetsu, ato, sanpaishori no machi naoshima no genzai (The present situation in Naoshima, a town of copper industry, art and industrial waste processing). Senshu daigaku shakai kagaku kenhyosho geppo, 2012 587/588, 23-54.

15 Funck and Chang, 86.

16 Porter International Website. https://www.II-porter.com/about

17 Art Setouchi Website. http://setouchi-artfest.jp/en/artworks-artists/artworks/ naoshima/2.html

18 Naoshima Island Developments Brochure. 2016. Available at Naoshima City Hall.

19 Conversation with Uyajino Umi Proprietress, May 16, 2017.

20 SANAA's cloud-like pavilion serves as a ferry terminal for a japanese island. Philip Stevens, August 22, 2017. https://www.designboom.com/architecture/ sanaa-naoshima-port-terminal-cloud-pavilion-japan-08-22-2017/

21 Conversation, May 16, 2017.

22 Jilly Traganou, The Tōkaidō Road, Routledge, 2004: 4.

23 Mira Locher, "Buying Brand-Name Building for Rural Revitalization in Japan" Perspecta 47: Money, James Andrachuk, Christos C. Bolos, Avi Forman, Marcus A. Hooks eds, 2014, 59.

24 Ibid, 59.

25 Ibid, 65

26 Anthony S. Rausch (2014) Japan's Heisei municipal mergers and the contradictions of neo-liberal administrative planning, Asia Pacific Journal of Public Administration, 36:2, 135.

27 Funck and Chang, 88-89.

28 Ibid, 89.

29 Japan Tourism Growing Rapidly. Deutsche Welle, October 01, 2017. http:// www.dw.com/en/japan-tourism-growing-rapidly/a-37071368

30 "The Future of Japan's Tourism: Path Towards Sustainable Growth Towards 2020" McKinsey \& Company, October 2016.

31 Anthony Rausch, Cultural commodities in Japanese Rural Revitalization: Tsugaru Nuri Lacquerware and Tsugaru Shamisen. Brill, 2010, 5.

32 Funck and Chang, 88.

\section{ALL IMAGES BY AUTHOR}

